\title{
Peran pemerintah Kota Batu dalam implementasi kebijakan pembangunan pariwisata berdasarkan paradigma pembangunan berkelanjutan (sustainable development)
}

\section{The role of Government of Batu on the implementation of tourism policy based on sustainable development paradigm}

\author{
Asih Widi Lestari, Firman Firdausi \\ Ilmu Administrasi Negara, Universitas Tribhuwana Tunggadewi Malang \\ Jalan Telaga Warna Blok C, Tlogomas, Lowokwaru, Malang 65144 E-mail: \\ widilestari263@gmail.com; firman.firdausi.88@gmail.com
}

\begin{abstract}
Indonesia is a country with rich and diverse natural resources. Batu is a city in Indonesia which popular because of its tourism potential. In the effort to develop the tourism, the Government of Batu designed several tourism policies. In tourism development, Government of Batu refer to sustainable development. This article tries to describe and analyze the role of Government of Batu to implement the tourism development policy based on the sustainable development paradigm. Research method used is descriptive qualitative using primary and secondary data. Data gathered through observation, interview, and documentation. This research found that the implementation of tourism policy in Batu has met the principles of sustainable development namely, economic welfare, sustainable environment, social justice, and living environment oriented. The Government of Batu plays significant role in creating the policy in general and regulating permissions, implementing prosociety policy and controlling private sectors investment in Batu.
\end{abstract}

Keywords: policy, tourism, sustainable development

\begin{abstract}
Abstrak
Indonesia merupakan negara yang sangat kaya akan potensi sumber daya alam yang sangat beragam. Kota Batu merupakan salah satu kota di Provinsi Jawa Timur yang sangat terkenal dengan pariwisatanya. Sebagai upaya pengembangan pariwisata, Pemerintah Kota Batu mengeluarkan kebijakan-kebijakan tentang pembangunan pariwisata. Dalam pengembangan pariwisata tersebut, Pemerintah Kota Batu tidak terlepas dari prinsipprinsip pembangunan berkelanjutan. Tujuan penelitian ini adalah untuk mendeskripsikan dan menganalisis peran Pemerintah Kota Batu dalam implementasi kebijakan pembangunan pariwisata berdasarkan paradigma pembangunan berkelanjutan. Penelitian ini menggunakan metode penelitian deskriptif kualitatif. Sumber data yang digunakan adalah data primer dan data sekunder. Teknik pengumpulan data dengan observasi, wawancara dan dokumentasi. Penelitian ini menemukan bahwa implementasi kebijakan pembangunan pariwisata di Kota Batu sesuai dengan prinsip-prinsip pembangunan berkelanjutan, yaitu pro ekonomi kesejahteraan, pro lingkungan berkelanjutan, pro keadilan sosial, dan pro lingkungan hidup. Pemerintah Kota Batu berperan dalam menyukseskan kebijakan tersebut adalah pembuat kebijakan secara umum dan regulasi perizinan serta kebijakan yang memihak pada masyarakat dan mengontrol pihak-pihak swasta yang berinvestasi di Kota Batu.
\end{abstract}

Kata kunci: kebijakan, pariwisata, pembangunan berkelanjutan

\section{Pendahuluan}

Indonesia merupakan daerah tujuan wisata yang sangat potensial untuk dikerjakan. Indonesia memiliki beranekaragam budaya, adat-istiadat, dan keindahan alam yang tidak dimiliki negara lain. Keberagaman budaya dan keindahan alam Indonesia menjadi daya tarik tersendiri bagi para wisatawan mancanegara. Wisatawan mancanegara mengenal kebudayaan Indonesia sangat beragam dan masyarakat Indonesia yang terkenal ramah-ramah, sehingga wisatawan mancanegara tertarik untuk berkunjung ke Indonesia.

Pariwisata adalah suatu industri yang sangat potensial. Pariwisata saat ini merupakan suatu industri yang sedang berkembang pesat, dalam hal ini pariwisata akan berkembang menjadi salah satu industri yang tumbuh dominan di berbagai belahan dunia. Banyak negara yang mengembangkan pariwisata sebagai sektor unggulan dari negaranya, karena sektor pariwisata adalah pembangkit usaha ekonomi potensial, dan pembangkit perekonomian suatu negara, kota, provinsi, kabupaten atau daerah tujuan pengunjung. 
Pembangunan pariwisata merupakan peran yang sangat penting bagi pembangunan suatu wilayah. Dengan adanya berbagai kegiatan pariwisata, maka daerah-daerah yang memiliki potensi dasar pariwisata akan lebih berkembang dan maju, selain itu pariwisata di beberapa daerah dapat memberikan dampak positif dalam perekonomiannya, terutama pemasukan devisa.

Pariwisata memiliki peran penting dan memiliki dampak positif terhadap pendapatan negara dan daerah. Adanya berbagai misi kepariwisataan, maka daerah yang memiliki potensi dasar pariwisata cenderung mengembangkan potensi daerah yang ada, sehingga diharapkan mampu menarik wisatawan dalam jumlah yang besar.

Salah satu daerah di Indonesia yang sedang mengembangkan pembangunan pariwisatanya adalah Kota Batu, Jawa Timur. Sejak berdiri sebagai daerah otonom pada tahun 2001, Kota Batu menetapkan dan memantapkan daerahnya sebagai Sentra Pariwisata dan Agropolitan, khususnya di Provinsi Jawa Timur (Sukmana 2009). Hal ini dituangkan dalam Rencana Induk Pengembangan Pariwisata Daerah Kota Batu Tahun 2010-2020 dan Peraturan Daerah Kota Batu Nomor 7 Tahun 2011 tentang Rencana Tata Ruang Wilayah Kota Batu 2010-2030, yaitu meningkatkan posisi dan peran Kota Batu dari kota wisata menjadi sentra wisata yang diperhitungkan di tingkat regional atau bahkan nasional, dengan melakukan penambahan ragam objek dan atraksi wisata, yang didukung oleh sarana dan prasarana, serta unsur penunjang wisata yang memadai dengan sebaran yang relatif merata di wilayah Kota Batu guna memperluas lapangan pekerjaan dalam rangka mengatasi pengangguran dan meningkatkan pendapatan warga maupun PAD Kota Batu yang berbasis pariwisata. Hal ini sejalan dengan visi

Kota Batu, yaitu Kota Batu sebagai Kota Wisata dan Agropolitan di Jawa Timur. Kota Batu memiliki potensi pariwisata yang besar, baik wisata alam, buatan, maupun budaya yang ditunjang dengan adanya fasilitas pendukung, berupa hotel dan perdagangan souvenir atau cinderamata.

Dengan adanya upaya pengembangan pariwisata di Kota Batu, diharapkan Kota Batu semakin baik dalam bidang hal pembangunan terutama pembangunan pariwisata. Di mana paradigma pembangunan yang baik adalah pembangunan berkelanjutan yang menggunakan empat tolak ukur yang meliputi: pro ekonomi kesejahteraan, pro lingkungan berkelanjutan, pro keadilan sosial, dan pro lingkungan hidup (Sutisna 2006).

Tujuan dari penelitian ini adalah untuk mendeskripsikan dan menganalisis peran Pemerintah Kota Batu dalam implementasi kebijakan pembangunan pariwisata berdasarkan paradigma pembangunan berkelanjutan (sustainable development).

\section{Kebijakan publik dan implementasi kebijakan}

Chief J.O. Udoji (Solichin 2008:5), mendefinisikan kebijakan publik sebagai: "an sanctioned course of action addressed to a particular problem or group of related problems that affect society at large" (suatu tindakan bersanksi yang mengarah pada suatu tujuan tertentu yang diarahkan pada suatu masalah atau sekelompok masalah tertentu yang saling berkaitan yang mempengaruhi sebagian besar warga masyarakat). Menurut Gordon (Keban 2008:76), implementasi adalah berkenaan dengan berbagai kegiatan yang diarahkan pada realisasi program. Dalam hal ini, administrator mengatur cara untuk mengorganisir, menginterpretasikan dan menerapkan kebijakan yang telah diseleksi. Mengorganisir berarti mengatur sumber daya, unit-unit, dan metode-metode untuk melaksanakan program. Melakukan interpretasi berkenaan dengan menterjemahkan bahasa atau istilah-istilah program ke dalam rencana-rencana dan petunjuk-petunjuk yang dapat diterima dan feasible. Menerapkan berarti menggunakan instrumen-instrumen, mengerjakan atau memberikan pelayanan rutin, serta melakukan pembayaran-pembayaran. Dengan kata lain, implementasi merupakan tahap merealisasi tujuan-tujuan program. 


\section{Pembangunan berkelanjutan (sustainable development)}

Suryono (2010:21) mengatakan bahwa sustainability diartikan sebagai suatu pembangunan untuk memenuhi kebutuhan generasi saat ini tanpa merugikan kebutuhan generasi masa datang. Resiko dan konsekuensi dari setiap pembangunan saat ini seharusnya tidak semuanya diwariskan kepada generasi mendatang, melainkan harus dipertimbangkan secara adil bagi generasi sekarang dan generasi massa mendatang.Undang-Undang No. 32 Tahun 2009 tentang Perlindungan dan Pengelolaan Lingkungan Hidup, mendefinisikan pembangunan berkelanjutan adalah upaya sadar dan terencana yang memadukan aspek lingkungan hidup, sosial, dan ekonomi ke dalam strategi pembangunan untuk menjamin keutuhan lingkungan hidup, serta keselamatan, kemampuan, kesejahteraan, dan mutu hidup generasi masa kini dan generasi masa depan.

Sutisna (2006:9), memaparkan bahwa terdapat empat indikator yang dapat dijadikan tolok ukur pembangunan berkelanjutan secara sederhana yang dapat digunakan baik untuk pemerintah pusat maupun di daerah untuk menilai keberhasilan seorang Kepala Pemerintahan dalam pelaksanaan proses pembangunan berkelanjutan. Adapun empat tolak ukur tersebut meliputi: 1) pro ekonomi kesejahteraan adalah pertumbuhan ekonomi ditujukan untuk kesejahteraan semua anggota masyarakat, dapat dicapai melalui teknologi inovatif yang berdampak minimum terhadap kerusakan lingkungan, 2) pro lingkungan berkelanjutan adalah menyangkut tentang etika lingkungan non antroposentris yang menjadi pedoman hidup masyarakat, sehingga mereka selalu mengupayakan kelestarian dan keseimbangan lingkungan, konservasi sumber daya alam vital, dan mengutamakan peningkatan kualitas hidup non material, 3) pro keadilan sosial adalah keadilan dan kesetaraan akses terhadap sumber daya alam dan pelayanan publik, menghargai diversitas budaya dan kesetaraan gender, dan 4) pro lingkungan hidup (pro-environment), yaitu mengenai beberapa indikator yang dapat digunakan untuk mengukurnya. Salah satunya adalah indeks kesesuaian, seperti misalnya nisbah luas hutan terhadap luas wilayah (semakin berkurang atau tidak), nisbah debit air sungai dalam musim hujan terhadap musim kemarau, kualitas udara, dan sebagainya.

\section{Pembangunan pariwisata}

Definisi tentang pariwisata oleh Matheison \& Wall yang dikutip oleh Chris Cooper sebagai berikut: "tourism is temporary movement to destination outside the normal home and workplace, the activities undertaken during the stay and the facilities created to cater for the needs of tourist" (Cooper et al. 1993).

Pembangunan pariwisata bertujuan untuk memberikan keuntungan bagi wisatawan maupun komunitas tuan rumah. Dengan adanya pembangunan pariwisata diharapkan mampu meningkatkan taraf hidup masyarakat melalui keuntungan secara ekonomi yang dibawa ke kawasan tersebut. Dengan kata lain pembangunan pengembangan pariwisata melalui penyediaan fasilitas infrastruktur, wisatawan dan penduduk setempat akan saling diuntungkan. Pengembangan tersebut sangat memperhatikan berbagai aspek, seperti aspek budaya, sejarah dan ekonomi daerah tujuan wisata. Pada dasarnya pengembangan pariwisata dilakukan untuk memaksimalkan keuntungan dan meminimalkan permasalahan (Mill 2000:168). Pengembangan pariwisata secara mendasar memperhatikan beberapa konsep, seperti: (1) pengembangan pariwisata berkelanjutan, (2) pembangunan wilayah terpadu dan pengembangan produk wisata, (3) pembangunan ekonomi pariwisata, dan (4) pengembangan lingkungan.

\section{Metode Penelitian}

Penelitian ini menggunakan metode penelitian deskriptif dengan pendekatan kualitatif. Sumber data yang digunakan adalah data primer dan data sekunder. Teknik pengumpulan data dengan observasi, wawancara dan dokumentasi. Instrumen penelitian yang digunakan adalah peneliti, pedoman wawancara, dan catatan lapangan. Metode analisis data yang digunakan adalah analisis model interaktif oleh Miles \& Huberman (1992:20), yaitu dengan cara pengumpulan data, reduksi data, 
penyajian data, dan simpulan. Pada penelitian ini yang menjadi lokasi penelitian adalah Kota Batu. Fokus penelitian adalah implementasi kebijakan pembangunan pariwisata berdasarkan paradigma pembangunan berkelanjutan (sustainable development): komunikasi, resources, disposition, dan struktur birokrasi.

Peran Pemerintah Kota Batu adalah membuat regulasi perizinan, serta menjalankan dan mengontrol kemitraan. Faktor pendukung dan penghambat dalam implementasi kebijakan pembangunan pariwisata berdasarkan paradigma pembangunan berkelanjutan (sustainable development) yang meliputi faktor pendukung dan faktor penghambat.

\section{Hasil Penelitian dan Pembahasan}

Kota Batu mempunyai kekayaan wisata alam yang panoramanya indah dan menawan, terletak di kawasan pegunungan, suhu udara terasa sejuk dan tidak lembab. Kondisi tersebut sangat baik untuk pertanian dan perkebunan dengan pengembangan pariwisata yang bernuansa alam, sehingga menjadikan Kota Batu sebagai sentra pertanian dan pariwisata. Oleh karena itu, Kota Batu sangat terkenal sebagai daerah tujuan wisata andalan di wilayah Kabupaten Malang dan salah satu primadona objek wisata di Provinsi Jawa Timur.

Kota Batu berada di daerah yang subur, maka juga terkenal dengan hasil buminya. Kota Batu secara geologis memiliki daerah yang mempunyai air tanah yang berlimpah. Sumber-sumber air ini dimanfaatkan untuk pelayanan air bersih (PDAM). Pasokan air ini tidak hanya dinikmati oleh warga Batu saja, namun juga oleh warga dari daerah-daerah sekitarnya, seperti Kabupaten dan Kota Malang. Dengan adanya sumber air, banyak hasil bumi yang dihasilkan, seperti pertanian, perkebunan, holtikultura, bunga dan tanaman toga.

\section{Implementasi kebijakan pembangunan pariwisata berdasarkan paradigma pembangunan berkelanjutan (sustainable development)}

Gordon (Keban 2008:76) mengatakan bahwa implementasi kebijakan adalah berkenaan dengan berbagai kegiatan yang diarahkan pada realisasi program. Di dalam teori tentang implementasi kebijakan publik, terdapat model-model implemetasi kebijakan yang di dalamnya terdapat indikator untuk mengukur keberhasilan implementasi sebuah kebijakan. Salah satu model implementasi kebijakan yang terkenal adalah Model Edward III. George Edward III (Nugroho 2009:512), menegaskan bahwa masalah utama administrasi publik adalah lack of attention to implementation. Dikatakannya, without effective implementation the decision of policymakers will not be carried out successfully. Edward menyarankan untuk memperhatikan empat isu pokok supaya implementasi kebijakan menjadi efektif, yaitu communication, resource, disposition or attitudes, dan bureaucratic structures. Dalam mengimplementasikan kebijakan pembangunan pariwisata di Kota Batu, sudah dapat dikatakan berhasil, yakni dilihat dari empat indikator dalam model implementasi kebijakan Edward III, yaitu komunikasi, resources, disposition, dan struktur birokrasi.

\section{Komunikasi}

Menurut Model Edward III, komunikasi berkenaan dengan bagaimana kebijakan dikomunikasikan pada organisasi dan/atau publik, ketersediaan sumber daya untuk melaksanakan kebijakan, sikap dan tanggap dari para pihak yang terlibat, dan bagaimana struktur organisasi pelaksana kebijakan. Komunikasi antar aktor kebijakan pembangunan pariwisata di Kota Batu sudah cukup baik. Hal ini terlihat adanya kerjasama antar SKPD terkait dalam mengimplementasikan kebijakan pembangunan pariwisata di Kota Batu. Komunikasi dengan masyarakat Batu juga sudah dilakukan oleh Pemerintah Kota Batu, bahkan dalam mengembangkan pariwisata di Kota Batu, pemerintah Kota Batu juga turut serta mengajak masyarakat. Pemerintah Kota Batu membentuk POKDARWIS (Kelompok Sadar Wisata) dalam masyarakat. Tujuannya adalah memberikan peluang kepada masyarakat untuk memberikan ide-ide atau gagasan dalam upaya pengembangan pariwisata di Kota Batu. 


\section{Resources}

Menurut Model Edward III, resource berkenaan dengan ketersediaan sumber daya pendukung khususnya sumber daya manusia. Hal ini berkenaan dengan kecakapan pelaksana kebijakan publik untuk carry out kebijakan secara efektif. Adanya aktor implementasi kebijakan paling penting dalam keberhasilan sebuah kebijakan. Dalam implementasi kebijakan pariwisata di Kota Batu, aktor utamanya adalah Pemerintah Kota Batu sendiri. Pemerintah Kota Batu juga bekerja sama dengan pihak swasta dan masyarakat dalam upaya pengembangan pariwisata di Kota Batu.

\section{Disposition}

Menurut Model Edward III, disposition berkenaan dengan kesediaan dari para implementator untuk carry out kebijakan publik tersebut. Kecakapan saja tidak mencukupi tanpa kesediaan dan komitmen untuk melaksanakan kebijakan. Kesediaan dan komitmen dari para aktor kebijakan pembangunan pariwisata di Kota Batu dapat dikatakan baik. Hal ini terlihat dari para aktor yang sudah mengetahui tugas dan perannya masing-masing. Tugas dari Pemerintah Kota Batu dalam mengembangkan kebijakan pariwisata di Kota Batu adalah membuat regulasi terkait pengembangan wisata di Kota Batu, mendampingi masyarakat supaya terlibat dalam pengembangan pariwisata di Kota Batu, menjalin kerjasama dengan pihak swasta supaya berinvestasi di bidang pariwisata di Kota Batu, serta memonitoring dan mengevaluasi jalannya kebijakan pengembangan pariwisata di Kota Batu.

\section{Struktur birokrasi}

Menurut Model Edward III, struktur birokrasi berkenaan dengan kesesuaian organisasi birokrasi yang menjadi penyelenggara implementasi kebijakan publik. Tantangannya adalah bagaimana supaya tidak terjadi bureaucratic fragmentation karena struktur ini menjadikan proses implementasi menjadi lebih jauh dari efektif. Struktur birokrasi di Kota Batu sudah dibentuk melalui SKPD terkait dalam melaksanakan kebijakan pembangunan pariwisata di Kota Batu. SKPD tersebut sudah mengerti tugas dan tanggung jawabnya masing-masing. Di dalam SKPD juga memiliki sub-sub bidang yang lebih terinci yang memiliki tugas dalam pengembangan pariwisata di Kota Batu. Dalam upaya pengembangan pariwisata Kota Batu, Pemerintah Kota Batu tidak mengesampingkan prinsip-prinsip pembangunan berkelanjutan (sustainable development). Sutisna (2006:9), memaparkan bahwa terdapat empat indikator yang dapat dijadikan tolok ukur pembangunan berkelanjutan secara sederhana yang dapat digunakan baik untuk pemerintah pusat maupun di daerah untuk menilai keberhasilan seorang Kepala Pemerintahan dalam pelaksanaan proses pembangunan berkelanjutan. Adapun empat tolok ukur tersebut meliputi: 1) pro ekonomi kesejahteraan, 2) pro lingkungan berkelanjutan, 3) pro keadilan sosial, dan 4) pro lingkungan hidup (pro-environment).

\section{Pro ekonomi kesejahteraan}

Proekonomi kesejahteraan adalah pertumbuhan ekonomi ditujukan untuk kesejahteraan semua anggota masyarakat, dapat dicapai melalui teknologi inovatif yang berdampak minimum terhadap kerusakan lingkungan. Dalam implementasi pengembangan pariwisata di Kota Batu, Pemerintah Kota Batu juga melibatkan masyarakat Kota Batu di dalamnya. Pemerintah Kota Batu juga memberikan pembinaanpembinaan terhadap usaha kecil menengah supaya produknya dapat dipasarkan di lokasi-lokasi pariwisata di Kota Batu, sehingga dengan adanya hal tersebut akan membantu menaikkan pendapatan masyarakat Batu (Sutisna 2006:9).

\section{Pro lingkungan berkelanjutan}

Pro lingkungan berkelanjutan adalah menyangkut tentang etika lingkungan non antroposentris yang menjadi pedoman hidup masyarakat, sehingga mereka selalu mengupayakan kelestarian dan keseimbangan lingkungan, konservasi sumber daya alam vital, dan mengutamakan peningkatan kualitas hidup non material. Hal ini juga dilakukan oleh pemerintah Kota Batu dalam implementasi kebijakan pengembangan pariwisata. Dalam upaya tetap menjaga kelestarian lingkungan, maka Pemerintah Kota Batu membuat pemetaan terhadap kawasan yang dilindungi atau tidak boleh digunakan untuk kegiatan komersial (Sutisna 2006:9). 


\section{Pro keadilan sosial}

Pro keadilan sosial adalah keadilan dan kesetaraan akses terhadap sumber daya alam dan pelayanan publik, menghargai diversitas budaya dan kesetaraan gender. Dalam mengimplementasikan kebijakan pengembangan pariwisata di Kota Batu, Pemerintah Kota Batu memberikan peluang kepada seluruh masyarakat Batu untuk ikut berpartisipasi dalam pengembangan pariwisata. Pemerintah Kota Batu juga memberikan pembinaan kepada seluruh masyarakat Batu.

\section{Pro lingkungan hidup}

Pro lingkungan hidup yaitu mengenai beberapa indikator yang dapat digunakan untuk mengukurnya. Salah satunya adalah indeks kesesuaian, misalnya nisbah luas hutan terhadap luas wilayah (semakin berkurang atau tidak), nisbah debit air sungai dalam musim hujan terhadap musim kemarau, kualitas udara, dan sebagainya. Selain membuat pemetaan terhadap kawasan yang dilindungi, Pemerintah Kota Batu juga sangat ketat dalam memberikan IMB terhadap investor yang masuk. Pemerintah Kota Batu juga memberikan sanksi yang tegas untuk para investor yang melanggar aturan dan menyebabkan kerusakan lingkungan (Sutisna 2006:9).

\section{Simpulan}

Kota Batu merupakan salah satu kota di Jawa Timur yang terkenal pariwisatanya, baik wisata alam maupun wisata buatan. Dalam melakukan pengembangan pariwisata di Kota Batu, Pemerintah Kota Batu sudah membuat kebijakan-kebijakan dalam upaya pengembangan pariwisata. Dalam implementasi kebijakan-kebijakan tersebut dikatakan sudah berhasil, dilihat dari indikator implementasi kebijakan dari Model Edward III, yaitu komunikasi, resources, disposition, dan struktur birokrasi. Implementasi kebijakan pembangunan pariwisata di Kota Batu sudah sesuai dengan prinsip-prinsip pembangunan berkelanjutan (sustainable development), yaitu pro ekonomi kesejahteraan, pro lingkungan berkelanjutan, pro keadilan sosial, dan pro lingkungan hidup. Dalam keberhasilan implementasi kebijakan pembangunan pariwisata Kota Batu berdasarkan paradigma pembangunan berkelanjutan, tidak terlepas dari peran Pemerintah Kota Batu. Adapun peran Pemerintah Kota Batu dalam mensukseskan kebijakan tersebut adalah pembuat kebijakan (Policy) secara umum dan regulasi perizinan serta kebijakan yang memihak pada masyarakat dan mengontrol pihak-pihak swasta yang berinvestasi di Kota Batu.

\section{Ucapan Terima Kasih}

Penulis selaku peneliti di sini menyampaikan terima kasih atas pendanaan penelitian oleh Dirjen Ristekdikti melalui program Penelitian Dosen Pemula (PDP) Tahun Anggaran 2017.

\section{Daftar Pustaka}

Cooper C, Fletcher J, Gilbert D, Wanhill S (1993) Tourism Principles and Practice, 1st end. London: Pitman Publishing.

Keban YT (2008) Enam Dimensi Strategis Administrasi Publik: Konsep, Teori, dan Isu, Edisi 2. Yogyakarta: Gava Media.

Miles MB \& Huberman MA (1992) Analisis Data Kualitatif. Bandung: PT. Remaja Rosdakarya.

Mill RC (2000) The Tourism International Business. Nj: Prentice Hall

Nugroho R (2009) Public Policy. Jakarta: PT. Elex Media Komputindo Kelompok Gramedia.

Solichin AW (2008) Analisis Kebijaksanaan: Dari Formulasi ke Implementasi Kebijaksanaan Negara, Edisi 2. Jakarta: Bumi Aksara.

Sukmana O (2007) Model Pengembangan Lingkungan Kota Ekowisata. Universitas Muhammadiyah Malang.

Suryono A (2010) Dimensi-Dimensi Prima Teori Pembangunan. Malang: UB Press.

Sutisna N (2006) Enam Tolok Ukur Pembangunan Berkelanjutan. Jakarta: Regional Development Institute. 